\title{
EFFICIENCY OF ZINC IN PLANTS, ITS DEFICIENCY AND SENSITIVITY FOR DIFFERENT CROPS
}

\author{
Daaraib Tayyiba ${ }^{1}$ \\ Hooria Zafar ${ }^{2}$ \\ Aqarab Husnain \\ Gondal $^{3+}$ \\ Qammar Farooq ${ }^{4}$ \\ Muhammad \\ Muzammil Mukhtar 5 \\ Rizwan Hussain ${ }^{6}$ \\ Nauman Aslam ${ }^{7}$ \\ Amna Muzaffar ${ }^{8}$ \\ Ismat Sattar ${ }^{9}$
}

\author{
${ }_{1,29,4,5,5,7,8,9,0}$ Institute of Soil and Environmental Sciences, University of \\ Agriculture Faisalabad, Punjab, Pakistan. \\ 'Email: laraibtayyiba228@gmail.com Tel: +923077814908 \\ EEmail: huriazaffar48@gmail.com Tel: +923084121125 \\ ${ }^{3}$ Email:aqarabhusnain944@gmail.com Tel:+923415831944 \\ ${ }^{4} E$ mail: qammarfarooq742@gmail.com Tel: +923160688683 \\ Email: Mukhtar.muzamil23@gmail.com Tel: +9233036356001 \\ ${ }^{6}$ Email: rizwanhussain038@gmail.com Tel: +92305-8189086 \\ 'Email: nauman.aslam2016@gmail.com Tel: +9234144446782 \\ ${ }^{8}$ Email:amna.muzaffar111@gmail.com Tel:+923410760093 \\ ${ }^{9} E m a i l:$ sattarjutt786@gmail.com Tel: +923345033337
}

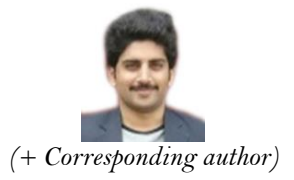

ABSTRACT

Optimal crop nutrition is a significant factor in increasing agricultural vintage and quality of products. Zinc $(\mathrm{Zn})$ is an immobile important micronutrient, which is taken up by plants in $\mathrm{Zn}^{2+}$ form to complete their life cycle efficiently. It plays a critical metabolic role in plants and is an important constituent of proteins and other largemolecules, and serves as structural and functional unit, or controlling cofactor for a wide range of enzymes. The $\mathrm{Zn}$ is needed in small and in appropriate amounts for plants main physiological processes to work normally. These processes play critical roles in photosynthetic activity of plants and forming carbohydrates, synthesis of protein, reproduction and seed development, growth, and disease protection. After $\mathrm{Zn}$ deficiency in plants, these physical functions are decreased, and plant health and productivity suffer greatly, subsequent in reduced production or even failure of crops and often bad quality of crop products. Plant $\mathrm{Zn}$ deficiencies occur on variety of soils and are severe due to a combination of symptoms like chlorosis, resetting, dieback and suppressed or irregular vegetative development. In addition, various crops require varying amount of $\mathrm{Zn}$. So the knowledge regarding this is not up to date. The present review discusses the $\mathrm{Zn}$ importance in plants, its deficiency in soil and required level of $\mathrm{Zn}$ for crops.

Contribution/Originality: The present review describes the efficiency of $\mathrm{Zn}$ in plants, its deficiency and sensitivity for different crops. This study is one of the very few studies that have investigated $\mathrm{Zn}$ importance in growth related processes and its effect on yield.

\section{INTRODUCTION}

Zinc $(\mathrm{Zn})$ is most essential nutrients that plants require in very small amount, for normal growth and development. It is one of the eighth micronutrients needed by plants. In plants, $\mathrm{Zn}$ is taken up and transferred in the form of $\mathrm{Zn}^{2+}$. The $\mathrm{Zn}$ with enzymes and proteins play an important role in metabolism of carbohydrates, auxin, protein synthesis, gene expression, pollen production, protection of cell membranes, and provide protection against 
biotic and abiotic stresses [1-4]. It is needed in small but essential for the normal operation of several main plant physiological paths [5]. Furthermore, it is a necessary component of crop production and fruit size, as well as the carbonic enzyme found in all photosynthetic tissues and compulsory for biosynthesis of chlorophyll [6-8]. In plants, $\mathrm{Zn}$ is an important micronutrient for synthesis of proteins; it is also a component of cell organelle like ribosomes and is needed for their formation. Pollen duct is one of the sites for synthesis of proteins, which contains 150 micrograms of $\mathrm{Zn}$ per gram of dry matter. Furthermore, $\mathrm{Zn}$ aid pollination by influencing pollen tube formation [9, 10]. The $\mathrm{Zn}$ can be linked to phospholipids of membranes or important constituent of sulfhydryl groups, or it can form compounds which are tetragonal in nature, with residues of Cysteine polypeptide chain, protecting proteins and lipids from oxidation damage [11].

The $\mathrm{Zn}$ is also a vital component of certain enzymes that are involved in the formation of enzymes of plants; additionally, it is involved in a variety of enzymatic reactions [12]. It is also plays a major role in alcohol dehydrogenase enzyme activity which contains two $\mathrm{Zn}$ atoms in which one atom play a catalytic role, while the other plays a role in building. This alcohol dehydrogenase enzyme catalyzes the acetaldehyde conversion into ethanol. Under aerobic conditions, higher plants produce ethanol in the root tips of meristematic tissue; however, deficiency of $\mathrm{Zn}$ reduces the activity of the alcohol dehydrogenase enzyme, resulting in reduced root growth [13]. The $\mathrm{Zn}$, is an important part of macromolecules, enzymes and proteins, and serves as operational, functional, or regulatory cofactor for an extensive range of enzymes. . It plays an important role in stabilization of RNA and DNA structure, DNA synthesizing enzyme activity maintenance, and RNA degrading enzyme activity regulation. As a result, $\mathrm{Zn}$ can play a role in regulation of gene expression [14]. Hence, $\mathrm{Zn}$ is a vital nutrient for plants due to its significant role in plant development and development as shown in Figure 1.

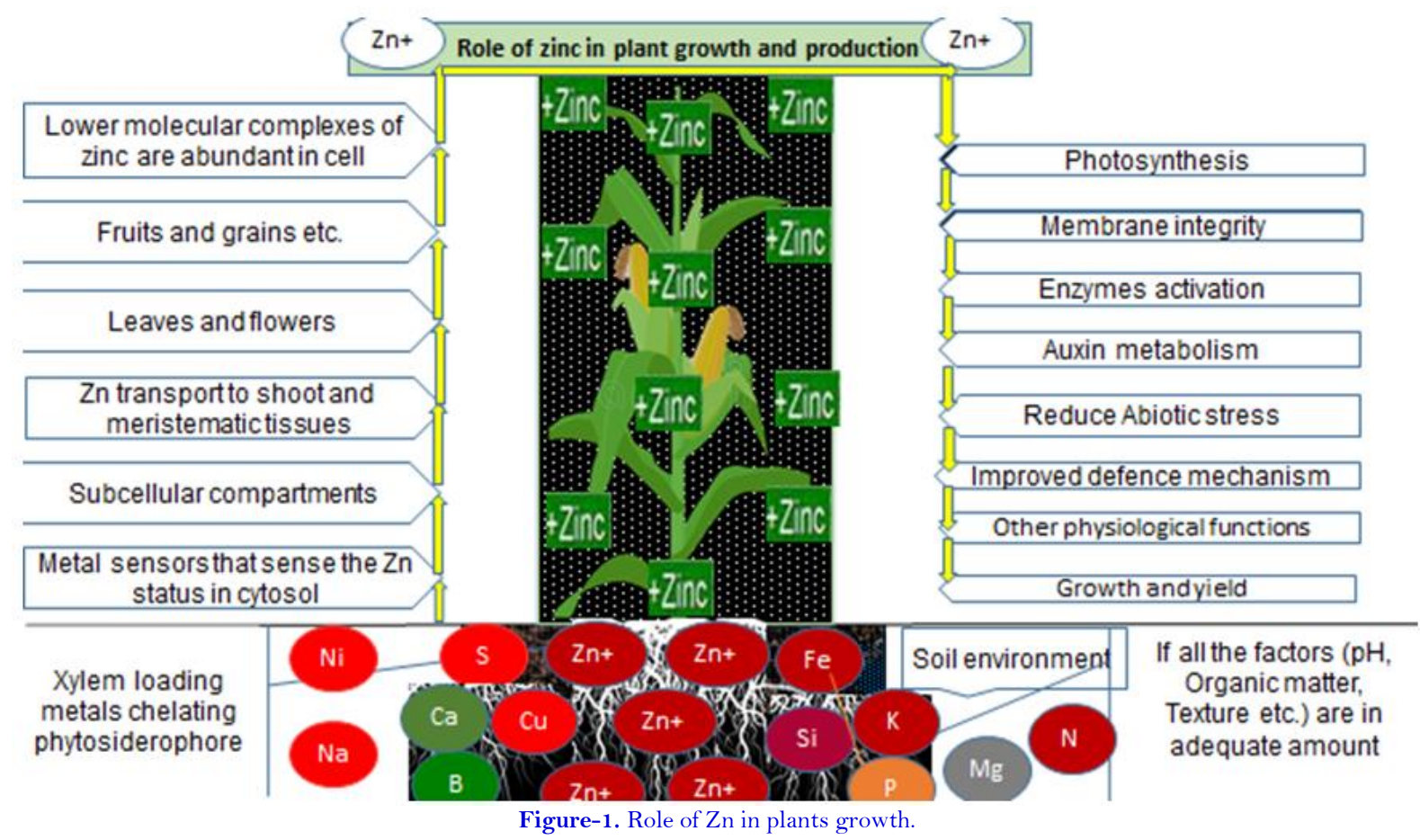

Very minute quantity of $\mathrm{Zn}$ is present in soil and on average it varies between $0.2-0.002 \mu \mathrm{g} \mathrm{Zn}$ per gram of soil. Due to fixation, high $\mathrm{pH}$ and other factors, its availability to plants is less [15]. In addition, the artificially applied $\mathrm{Zn}$ becomes fixed with soil by reacting with soil matrix. Furthermore, chelated Zn EDTA is extremely effective and accessible to maintenance of the plant progress, resulting in advanced production [16]. 


\subsection{Zn Deficiency in Plants}

$\mathrm{Zn}$ deficiency reduces amino acid accumulation in plant tissues and protein synthesis. Most of the physiological changes are caused by $\mathrm{Zn}$ deficiency, which are associated with disturbances in normal enzyme function; hence, $\mathrm{Zn}$ deficiency cause photosynthesis suppression accompanied by an activity of essential photosynthetic enzymes has decreased. The $\mathrm{Zn}$ shortage also leads to membrane dielectric breakdown by inhibiting the involvement of enzymes involved in the removal of harmful reactive oxygen species [17]. Sorghum plants are particularly vulnerable to zinc $(\mathrm{Zn})$ deficiency, which can cause oxidative stress, increased cellular osmotic potential, and a reduction in colour production and protein synthesis [18]. The $\mathrm{Zn}$ is immobile, so the deficiency symptoms occur first on new leaves of plants because it cannot be moved from older to younger leaves [19]. Stunted growth is one of the most common acute zinc deficiency symptoms. Other deficiency indicators of plants exhibit light green color of leaves, yellow, or bleached spots in interveinal parts of older leaves; young leaves are smaller in size, sometimes referred to as "little leaves," and exhibit resetting, in which the intermodal distance becomes so small that all the leaves appear to come out of the same single point [20] and the remaining symptoms and diseases as shown in Table 1.

Table-1. The $\mathrm{Zn}$ deficiency symptoms and diseases of various crops.

\begin{tabular}{|c|c|c|}
\hline Crops & Symptoms and Diseases & References \\
\hline Maize & $\begin{array}{l}\text { Chlorosis } \\
\text { Rosetting } \\
\text { White bud of maize }\end{array}$ & $\begin{array}{l}\text { Alloway [1] } \\
\text { McCoy, et al. [21] } \\
\text { Ata, et al. [22] } \\
\text { Lutts, et al. [23] }\end{array}$ \\
\hline Rice & $\begin{array}{l}\text { khaira disease } \\
\text { Hudda Disease } \\
\text { Bronzing }\end{array}$ & $\begin{array}{l}\text { Kushwaha [24] } \\
\text { Lutts, et al. [23] }\end{array}$ \\
\hline Sorghum, Soybean & Bronzing & Lutts, et al. [23] \\
\hline Apple & Rosetting/Little leaf & Lutts, et al. [23] \\
\hline Sugarbeet & & Motieeian, et al. [25] \\
\hline Grapefruit & Mottle-leaf & Freidberg [26] \\
\hline Tung & $\begin{array}{l}\text { Leaf bronzing } \\
\text { Necrosis } \\
\text { Spotting }\end{array}$ & Batchelor [27] \\
\hline Barley & Chlorosis & Yang $[28]$ \\
\hline Cotton & Leaves chlorotic with necrotic areas & Suvo, et al. [29] \\
\hline Potato & $\begin{array}{l}\text { Leave spot } \\
\text { Curling of leaves }\end{array}$ & Kambale $[30]$ \\
\hline Broad bean & Leaves and flower buds shed & Demski [31] \\
\hline Tomato & Leaves mottled and necrotic, leaflets small & Hamid [32] \\
\hline Garden pea & $\begin{array}{l}\text { Lower leaves have necrotic edges and tips; stems } \\
\text { stiff and erect; flowers none. }\end{array}$ & Smith, et al. [33] \\
\hline Garden bean & Leaves and flower buds shed. & Demski [31] \\
\hline Oat & $\begin{array}{l}\text { Leaves pale green } \\
\text { Necrosis extends down leaf, remainder of leaf gray } \\
\text { to bronze-green. }\end{array}$ & Idota, et al. [34] \\
\hline Squash & Leaves mottled with necrotic areas & $\begin{array}{l}\text { Benson and Grimstead } \\
\text { [35] }\end{array}$ \\
\hline
\end{tabular}

Overall, Zn deficiency has a greater impact on shoot growth than on root growth [2, 7]. Plant hormone metabolism, such as Indole acetic acid and tryptophan, declines in $\mathrm{Zn}$ deficiency, due to which leaf development ceases. In fact, zinc is required for tryptophan synthesis, which is required for the formation of auxin; hence, zinc deficiency reduces the amount of auxin [36].

By using fertilizers containing zinc and other micronutrients improves crop production, however when these elements are present in inadequate amount, this cause degeneration of photosynthesis process and the destruction of RNA, carbohydrates solution and protein synthesis decreases, lowering crop productivity and quality [37]. 


\subsection{Zn Deficiency in Soil}

Raulin discovered the biological function of $\mathrm{Zn}$ in 1869, when he observed that Aspergillus niger (a common bread mold) was unable to grow in $\mathrm{Zn}$ absence. Soon after, $\mathrm{Zn}$ was discovered to be a common part of both tissues of animal and plant. This discovery sparked $\mathrm{Zn}$ studies in crops, and in plants the first demonstration of deficiency of $\mathrm{Zn}$ occurred in 2021 [38]. Now, Zn deficiency has been most common micronutrient insufficiency in soils and crops around the world, resulting in significant crop losses and nourishing quality degradation. Nearly half of the world's soils are zinc deficient [39]. According to the UN's Food and Agriculture Organization (FAO), 50 percent of the world's cereals growing soils are $\mathrm{Zn}$ deficient. It also predicts that by 2050 , food manufacture will need to increase by $70 \%$ to feed the world's population of over 9 billion people [40]. Mostly Zn deficiency problems are found in calcareous, and weathered acidic soils. In these soils, iron deficiency is often followed by deficiency of $\mathrm{Zn}$. The adsorption of $\mathrm{Zn}$ from soil solution by clay and limestone particles causes $\mathrm{Zn}$ deficiency in these soils. A depletion of organic matter in eroded soils causes n deficiency. It can also be linked to conditions of weather; more common when weather is cold \& wet and may be attributed to a lack of root development in cool soils, as well as reduced microbe activity and $\mathrm{Zn}$ release from organic materials [7, 41]. Excessive bicarbonate $\left(\mathrm{HCO}_{3}\right)$ concentrations inhibit zinc uptake by plant shoots [42].

\subsection{Zn Sensitivity of Different Crops}

Numerous plant species, including, maize, bean, rice, wheat, tomatoes and rice, are considered to be less resistant to zinc deficiency and show major crop losses when compared to more tolerant plant species like carrots, rye and peas Table 2 [43]. The relative susceptibility of different crops to deficiency of zinc varies [1].

Table-2. Zn sensitivity of different crops

\begin{tabular}{l|l|l}
\hline Low Sensitive & Medium Sensitive & Highly Sensitive \\
\hline Asparagus & Alfalfa & Bean \\
\hline Carrot & Barley & Citrus \\
\hline Forage grasses & Clover & Cowpea \\
\hline Mustard & Cotton & Maize \\
\hline Oat & Sorghum & Millet \\
\hline Pea & Sugar beet & Onion \\
\hline Rye & Sugar can & Rice \\
\hline Wheat & Sunflower & - \\
\hline Paper mint & - & - \\
\hline
\end{tabular}

\section{CONCLUSION}

The $\mathrm{Zn}$ is required by plants in smaller amount and allow plants to perform their functions normally, mostly physiological. World's soils are usually deficient in $\mathrm{Zn}$ to meet the requirements of plants. To overcome the zinc deficiency there is need to raise awareness among farmers community about its importance with the help of extension workers and trying to correct zinc deficiency would increase yields and farmer income while also enhancing nutritional quality of crops and ultimately human nutrition. For higher crop yields, balanced fertilizer use with micronutrients such as zinc is needed.

Funding: This study received no specific financial support.

Competing Interests: The authors declare that they have no competing interests.

Acknowledgement: All the authors are highly thankful to Institute of Soil and Environmental

Sciences, University of Agriculture Faisalabad, Punjab, Pakistan for their moral support.

\section{REFERENCES}

[1] B. Alloway, Zinc in soils and crop nutrition. Paris, France, Brussels, Belgium: IFA, IZA, 2008. 
M. Gómez-Rey, A. Couto-Vázquez, and S. González-Prieto, "Age and thinning effects on elemental composition of," Pinus Pinaster, vol. 14, pp. 299-306, 202 1a. Available at: https://doi.org/10.3832/ifor3575-014.

A. H. Gondal, I. Hussain, A. B. Ijaz, A. Zafar, B. I. Ch, H. Zafar, M. D. Sohail, A. A. Khan, H. Niazi, and H. Yousaf, "Influence of soil $\mathrm{pH}$ and microbes on mineral solubility and plant nutrition: A review," International Journal of Agriculture and Biological Sciences, vol. 5, pp. 71-81, $2021 \mathrm{~b}$.

A. H. Gondal, A. Zafar, D. Zainab, M. Toor, S. Sohail, S. Ameen, A. Ijaz, B. Ch, I. Hussain, and S. Haider, "A detailed review study of zinc involvement in animal, plant and human nutrition," Indian Journal of Pure \& Applied Biosciences, vol. 9, pp. 262-271, 2021 c. Available at: https://doi.org/10.18782/2582-2845.8652.

K. Yosefi, M. Galavi, M. Ramrodi, and S. R. Mousavi, "Effect of bio-phosphate and chemical phosphorus fertilizer accompanied with micronutrient foliar application on growth, yield and yield components of maize (Single Cross 704)," Australian Journal of Crop Science, vol. 5, pp. 175-180, 2011.

M. Ali, B. Schiedt, K. Healy, R. Neumann, and W. Ensinger, "Modifying the surface charge of single track-etched conical nanopores in polyimide," Nanotechnology, vol. 19, p. 085713, 2008. Available at: https://doi.org/10.1088/09574484/19/8/085713.

S. Mousavi, "Zinc in crop production and interaction with phosphorus," Australian Journal of Basic and Applied Sciences, vol. 5, pp. 1503-1509, 2011.

B. I. Ch, A. H. Gondal, H. Zafar, H. Umar, M. D. Toor, A. Zafar, Q. Farooq, and S. Saeed, "A brief correspondence on glyphosate remediation using microbes and mineral sources," Annals of Reviews and Research, vol. 6, p. 555693, 2021.

M. R. Pandey, "Use of medicinal plants in traditional Tibetan therapy system in upper Mustang, Nepal," Our Nature, vol. 4, pp. 69-82, 2006. Available at: https://doi.org/10.3126/on.v4i1.505.

[10] S. S. Kumar, A. H. Gondal, F. Hayat, A. G. Mahale, Q. Farooq, and H. Umer, "Weed and disease eradication in crops through genetically modified microbes and soil microorganisms: A promising treatment," Journal of Agriculture and Allied fields, vol. 3, pp. 37-51, 2021.

[11] S. E. Smith and F. A. Smith, "Roles of arbuscular mycorrhizas in plant nutrition and growth: New paradigms from cellular to ecosystem scales," Annual Review of Plant Biology, vol. 62, pp. 227-250, 2011. Available at: https://doi.org/10.1146/annurev-arplant-042 110-103846.

[12] A. H. Gondal, H. Zafar, H. Yousaf, Q. Farooq, B. Imran, M. D. T. Ch, M. S. Tahir, M. Amin, M. Tariq, and A. Parveen, "Impacts of tillage technologies on soil, plant, environment and its management: A short communication," Indian Journal of Pure ङ Applied Biosciences, vol. 9, pp. 76-83, 202 1d. Available at: https://doi.org/10.18782/2582-2845.8682.

[13] H. Pan, R. Zhou, G. V. Louie, J. K. Mühlemann, E. K. Bomati, M. E. Bowman, N. Dudareva, R. A. Dixon, J. P. Noel, and X. Wang, "Structural studies of cinnamoyl-CoA reductase and cinnamyl-alcohol dehydrogenase, key enzymes of monolignol biosynthesis," The Plant Cell, vol. 26, pp. 3709-3727, 2014. Available at: https://doi.org/10.1105/tpc.114.127399.

[14] N. K. Fageria, The use of nutrients in crop plants: CRC Press, 2016.

[15] A. Husnain, Q. Farooq, S. Sohail, S. Shasang, D. Toor, A. Zafar, and B. Rehman, "Adaptability of soil pH through innovative microbial approach," Current Research in Agricultural Sciences, vol. 8, pp. 71-79, 2021. Available at: https://doi.org/10.18488/journal.68.2021.82.71.79.

[16] A. Haroon, T. Yaseen, A. Husnain, M. Mehfooz, M. H. Jarar, U. Naveed, and F. Khalid, "Water resources helps in the expansion of mosquitoes colonies," Big Data in Water Resources Engineering, vol. 1, pp. 16-2 1, 2020.

[17] B. Hafeez, Y. Khanif, and M. Saleem, "Role of zinc in plant nutrition-a review," American Journal of Experimental Agriculture, vol. 3, pp. 374-391, 2013. Available at: https://doi.org/10.9734/ajea/2013/2746.

[18] M. Chanchan, K. Ghosh, and K. Hore, "Potash fertilization of turmeric using organic as well as inorganic sources," Journal of Crop and Weed, vol. 14, pp. 69-74, 2018.

[19] S. Chatterjee, D. Mukherjee, S. Sharma, and P. Choudhuri, "Managing boron and zinc deficiency in vegetable crops," Innovative Farming, vol. 3, pp. 72-76, 2018. 
[20] N. Bala, S. Saha, M. Chakraborty, M. Maiti, S. Das, R. Basu, and P. Nandy, "Green synthesis of zinc oxide nanoparticles using Hibiscus subdariffa leaf extract: Effect of temperature on synthesis, anti-bacterial activity and antidiabetic activity," RSC Advances, vol. 5, pp. 4993-5003, 2015. Available at: https://doi.org/10.1039/c4ra12784f.

[21] A. McCoy, M. Roth, R. Shay, Z. Noel, M. Jayawardana, R. Longley, G. Bonito, and M. Chilvers, "Identification of fungal communities within the tar spot complex of corn in Michigan via next-generation sequencing," Phytobiomes Journal, vol. 3, pp. 235-243, 2019. Available at: https://doi.org/10.1094/pbiomes-03-19-0017-r.

[22] A. Ata, E. Amal, and A. M. Maysa, "Inducing resistance against sorghum downy Mildew disease of maize by some chemical inducers," Middle East Journal, vol. 1, pp. 76-84, 2012.

[23] S. Lutts, P. Benincasa, L. Wojtyla, S. Kubala, R. Pace, K. Lechowska, M. Quinet, and M. Garnczarska, "Seed priming: new comprehensive approaches for an old empirical technique," New Challenges in Seed Biology-Basic and Translational Research Driving seed Technology, pp. 1-46, 2016. Available at: https://doi.org/10.5772/64420.

[24] U. K. S. Kushwaha, "Black rice. In Black Rice: Springer, 2016. Retrieved from https://quod.lib.umich.edu/cgi/t/text/text-idx?c=acls;cc=acls;view=toc;idno=heb31688.0001.001," 2016.

[25] L. Motieeian, M. Nasresfahani, and M. Olia, "Correlation of root anatomical components with resistance in sugar beet genotypes to Cyst Nematode Heterodera schachtii Schmidt 1871," Journal of Plant Protection, vol. 32, pp. 147-156, 2018.

[26] S. Freidberg, "One refrigeration: Cold revolution. Harvard University Press. Retrieved from https://quod.lib.umich.edu/cgi/t/text/text-idx?c=acls;cc=acls;view=toc;idno=heb31688.0001.001," 2021.

[27] L. D. Batchelor, Chapter vii. Principles and methods of fertilization. In the Production of the Crop vol. 2: University of California Press, 2020.

[28] L. Yang, "The role of the seed microbiome of barley (Hordeum vulgare) as driver for the composition of root endophytes," Doctoral Dissertation, Technische Universität München, 2020.

[29] T. P. Suvo, M. S. Islam, M. S. I. Khan, M. N. H. Mehedi, and M. T. Ahamed, "Effects of soil and closed soilless system on growth, productivity, fruit quality, and plant mineral composition of zucchini squash," Octa Journal of Environmental Research, vol. 5, pp. 53-56, 2017.

[30] H. M. Kambale, "Genetic analysis of sweet potato (ipomoea batatas (1) lam) genotypes for beta carotene content and root yield in Kenya," Doctoral Dissertation, University of Nairobi, 2017.

[31] D. Demski, "Spaces of modernity: Ethnic shows in Poznań, 1879-1914," East Central Europe, vol. 47, pp. 202-232, 2020. Available at: https://doi.org/10.30965/18763308-04702003.

[32] R. E. A. Hamid, "Characterization and evaluation of Malam Elwedian land area for agricultural development North Darfur-Sudan," Doctoral Dissertation, Sudan University of Science and Technology, 2018.

[33] G. Smith, F. Rouquette Jr, and P. DeLaune, "'Ace'forage cowpea," Journal of Plant Registrations, vol. 14, pp. 126-133, 2020.

[34] N. Idota, K. Shintani-Ishida, H. Ichioka, H. Kondou, and H. Ikegaya, "Rapid infusion of excessive phenytoin: A newborn autopsy case," Legal Medicine, vol. 53, p. 101935, 2021. Available at: https://doi.org/10.1016/j.legalmed.2021.101935.

[35] L. V. Benson and D. N. Grimstead, "Prehistoric Chaco Canyon, New Mexico: Residential population implications of limited agricultural and mammal productivity," Journal of Archaeological Science, vol. 108, p. 104971, 2019. Available at: https://doi.org/10.1016/j.jas.2019.104971.

[36] J. F. Pedler, D. R. Parker, and D. E. Crowley, "Zinc deficiency-induced phytosiderophore release by the Triticaceae is not consistently expressed in solution culture," Planta, vol. 211, pp. 120-126, 2000. Available at: https://doi.org/10.1007/s004250000270.

[37] L. Efe and E. Yarpuz, "The effect of zinc application methods on seed cotton yield, lint and seed quality of cotton (Gossypium hirsutum L.) in east Mediterranean region of Turkey," African Journal of Biotechnology, vol. 10, pp. 87828789, 2011. Available at: https://doi.org/10.5897/ajb11.737. 
[38] G. Tamindžić, M. Ignjatov, D. Milošević, Z. Nikolić, L. K. Kravljanac, D. Jovičić, Ž. Dolijanović, and J. Savić, "Seed priming with zinc improves field performance of maize hybrids grown on calcareous chernozem," Italian Journal of Agronomy, vol. 16, 2021. Available at: https://doi.org/10.4081/ija.2021.1795.

[39] M. Tariq, F. Khan, A. Shah, S. Fahad, F. Wahid, J. Ali, M. Adnan, M. Ahmad, M. Irfan, and M. Zafar-ul-Hye, "Effect of micronutrients foliar supplementation on the production and eminence of plum (Prunus domestica L.)," Quality Assurance and Safety of Crops \& Foods, vol. 12, pp. 32-40, 2020. Available at: https://doi.org/10.15586/qas.v12isp 1.793.

[40] S. R. Mousavi, M. Galavi, and M. Rezaei, "Zinc (Zn) importance for crop production-a review," International Journal of Agronomy and Plant Production, vol. 4, pp. 64-68, 2013.

[41] M. Alam, M. Abedin, and M. Azad, "Effect of micronutrients on growth and yield of onion under calcareous soil environment," International Research Journal of Plant Science, vol. 1, pp. 056-06 1, 2010.

[42] E. Yılmaz, G. Naif, Ş. Sezer, D. Ayşegül, S. Necdettin, and A. Mine, "Interactive effects of humic acid and zinc on yield and quality in broccoli," Soil and Water Journal, vol. 1, pp. 287-293, 2013.

[43] S. Xue, F. Zhu, X. Kong, C. Wu, L. Huang, N. Huang, and W. Hartley, "A review of the characterization and revegetation of bauxite residues (Red mud)," Environmental Science and Pollution Research, vol. 23, pp. 1120-1132, 2016. Available at: https://doi.org/10.1007/s11356-015-4558-8.

Views and opinions expressed in this article are the views and opinions of the author(s), Current Research in Agricultural Sciences shall not be responsible or answerable for any loss, damage or liability etc. caused in relation to/arising out of the use of the content. 